\title{
Getting beta all the time: discovery of reliable markers of beta cell mass
}

\author{
J. C. Hutton • H. W. Davidson
}

Received: 22 February 2010 / Accepted: 26 March 2010/Published online: 22 April 2010

(C) Springer-Verlag 2010

Keywords Alternate splicing Beta cell mass $\cdot$ C-peptide . FXYD $\cdot \mathrm{Na}^{+}-\mathrm{K}^{+}$ATPase $\cdot$ Positron emission tomography . Phage display. Single chain antibody. Single photon emission computed tomography

Abbreviations
aa $\begin{array}{ll}\text { Amino acid } \\ \text { FXYD2 } \gamma & \begin{array}{l}\text { FXYD domain containing ion transport } \\ \text { regulator } 2 \text { gamma } \\ \text { Glucagon-like peptide } 1\end{array} \\ \text { GLP-1 } & \text { Neuropeptide Y } \\ \text { NPY } & \text { Vesicular monoamine transporter } 2\end{array}$

The long prodrome of type 1 diabetes, evidenced by the early appearance of circulating autoantibodies of multiple specificities, provides a window of opportunity for therapeutic intervention. Several ongoing Phase II and III clinical trials show promise that we will eventually be able to prevent the T-cell-mediated autoimmune destruction of the islet, probably by a combination of immune-based therapies and induction of beta cell growth or cellular replacement. Currently the efficacy of intervention postdisease-onset can be monitored by the decline in C-peptide responses along with $\mathrm{HbA}_{1 \mathrm{c}}$ levels and insulin requirements; however, these metrics are of little use before

J. C. Hutton $(\bowtie) \cdot H$. W. Davidson

Barbara Davis Center for Childhood Diabetes,

University of Colorado Denver,

Mail Stop B140, 1775 Aurora Court,

Aurora, CO 80045, USA

e-mail: John.Hutton@ucdenver.edu disease emergence, and there is an important strategic need to develop technologies to evaluate beta cell mass in human individuals, either serologically or by non-invasive imaging. The same applies to type 2 diabetes. Routine monitoring of beta cell mass will be an essential component of the management of future therapeutic interventions for determining efficacy and detecting disease recurrence.

The monoclonal antibody approach that provided hundreds of clusters of differentiation markers of the immune system in the 1980s has been less productive than might have been hoped in defining islet-specific cellsurface antigens. While several of the monoclonal antibodies generated by immunisation with islet subfractions and subsequent immunohistochemical screening show robust beta cell specificity, most seem to result from $\mathrm{T}$ cell-independent humoral responses to non-peptide antigens such as sulfatide phospholipids (1C2) [1] and gangliosides (3G5 and R2D6) [2-4]. Some of these monoclonal antibodies have found practical use in identifying and sorting different pancreas cell types and islet progenitors [5-7]; however, they have generally not found their way into the field of non-invasive islet imaging, even though the antigens appear relatively tissue-specific and abundant. This is in part because of their ill-defined cellular localisation and intractability to molecular cloning. Hence much of the development of imaging technologies for islets based on positron emission tomography and single photon emission computed tomography has been directed towards the use of high-affinity ligands of plasma membrane receptors such as glucagon-like peptide 1 (GLP-1) [8-10] and neuropeptide Y (NPY) [11], membrane channel components such as vesicular monoamine transporter 2 (VMAT2) [12], and the Kir6.2/sulfonylurea receptor complex, or more general metabolic functional markers [13]. 
The identification of two new potential targets is discussed in this issue. Flamez and colleagues [14] tackled the task of discovering new beta cell surface markers using a combination of massively parallel cDNA sequencing comparisons of multiple tissues [15] and microarray expression profiling of sorted beta and non-beta cells from isolated islets [16]. From an initial 950 islet specific genes, 114 were identified as localised at the membrane based on identification of signal sequences and hydrophobic membrane spanning helices (using the TMHMM program; www.cbs.dtu.dk/services/TMHMM/) in combination with knowledge-based pathway analysis (using Ingenuity software; www.ingenuity.com/). Of these, 44 were defined as preferentially expressed in beta vs non-beta cells, from which a subset of 12 were selected based on their nonresponsiveness to inflammatory cytokines. This latter criterion is important, in that assays based on gene transcripts with expression altered by cytokines, glucose or another diabetes-related change could be misinterpreted as a change in beta cell mass. While the list of transcripts identified by these authors overlaps with those identified previously by subtractive hybridisation selection [17] and cDNA microarray screening [18], their prime gene candidate, FXYD2 $\gamma a$, is an alternatively spliced variant of a common gene, which could only be identified from the newer, higher probe density, exon-specific microarrays [16] or by cDNA or exon sequencing approaches.

The paper by Ueberberg and colleagues [19] in this same issue takes the alternative approach of screening randomly generated probes for beta cell-specific binding. Starting with a human single chain antibody library $\left(1.5 \times 10^{8}\right.$ clones fused to the pIII bacteriophage coat protein) [20], the authors performed a negative selection with the rat pancreatic exocrine/ductal cell line AR42J, followed by five rounds of positive selection by panning on rat insulinoma INS-1E cells. A dominant clone was obtained (SCA-B5) that upon expression, radiolabelling and intravenous injection was found to bind selectively to rat pancreas. In vitro it bound specifically to islets, and with micromolar affinity to the cell surface of INS-1E cells. Somewhat remarkably, the $25 \mathrm{kD}$ SCA-B5 protein was concentrated intracellularly with a half-life of $6 \mathrm{~min}$, indicative of receptor-mediated endocytosis. Unfortunately, no informa- tion on the molecular size or chemical nature of the cellular ligand for SCA-B5 was provided. Four beta cell-specific single chain antibodies previously developed by these authors using a variant of the same technique [21] did not compete with SCA-5 binding, indicating that there might be multiple targets of this type; or alternately, a single target with multiple epitopes.

The beta cell-specific biomarker identified by Flamez and colleagues, FXYD2 $\gamma \mathrm{a}$, is an alternatively spliced form of FXYD2 $\gamma$, one of seven FXYD genes found in three distinct chromosomal locations that function as a third, regulatory, subunit of the ubiquitously distributed $\mathrm{Na}+-\mathrm{K}+$ ATPase [22]. FXYD genes encode transmembrane proteins that share a 35 amino acid (aa) signature sequence, beginning with the sequence Asp-Pro-Phe-X-Tyr-Asp and containing seven invariant and six highly conserved amino acids in a 19-20aa transmembrane spanning segment. Gene deletion studies show that although the $\mathrm{Na}+-\mathrm{K}+$ ATPase activity does not depend on the FXYD domain containing ion transport regulator 2 gamma (FXYD2 $\gamma$ ) subunit, the subunit plays a role in modulating the enzyme, both by inducing ion channel activity and lowering the $\mathrm{Km}$ value for $\mathrm{Na}$ ions [23, 24]. Two of the three alternatively spliced transcripts (isoforms a and b) (Fig. 1) are similar in size $(7.3 \mathrm{kD})$ and differ only in the first 6 aa of their NH2 termini, a result of using alternate first exons. The third (isoform c, Fig. 1) is larger (15.1 kD), and has the same $\mathrm{NH} 2$ terminus as isoform a, together with part of the $5^{\prime}$ untranslated region and presumably common proximal cisacting promoter elements. A key reagent in the study by Flamez and colleagues was a polyclonal antibody (SPY393) raised to the first 11aa of human FXYD2 ya that does not react to human FXYD2 $\gamma \mathrm{b}$. Given their close similarity, a potential concern was cross-reactivity with the FXYD2 $\gamma \mathrm{c}$ isoform, which the authors dismiss on the basis of PCR data, despite observing an immunoreactive protein of approximately an equivalent size to FXYD2 $\gamma \mathrm{c}$ on western blots probed with a commercial monoclonal antibody that is likely to see all FXYD2 $\gamma$ isoforms. Immunohistochemistry performed on paraffin sections of human pancreas nicely shows co-localisation of SPY393 immunoreactivity with insulin, but not with glucagon, pancreatic polypeptide or exocrine tissue. Pancreatic sec-

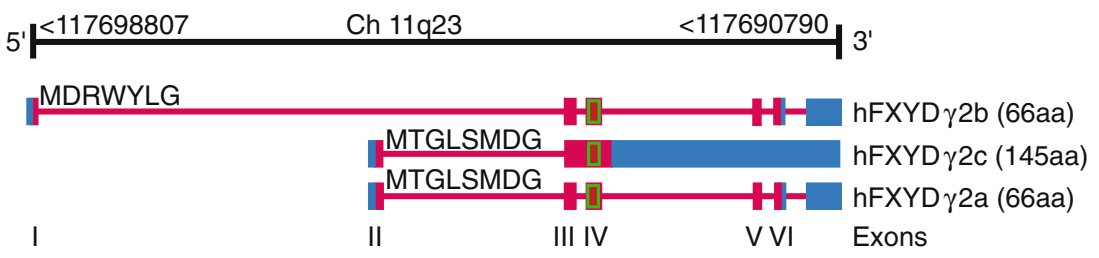

Fig. 1 Human $F X Y D 2 \gamma$ gene transcripts. All $F X Y D 2 \gamma$ transcripts share a common transmembrane domain (boxed in green) and the preceding FXY(D) sequence encoded by exon III. Exons I and II encode alternate $\mathrm{NH}_{2}$ termini (sequence shown) that distinguish the a and $\mathrm{b}$ isoforms. Red boxes, coding sequences; blue boxes, non-coding sequences 
tions from diabetic patients and non-human primates show parallel reduction in the numbers of insulin immunoreactive and SPY393-reactive cells on adjacent sections, substantiating the claim that reactivity is beta cell-specific in both islet and pancreas. This fits with the massively parallel signature sequencing (MPSS) results, which show that the frequency of FXYD2 $\gamma$ a transcripts in islets is 500-fold higher than whole pancreas. Less convincingly, microarray data indicate only a 1.25 -fold difference in production of FXYD2 $\gamma$ a between FACS-sorted beta cells and non-beta cells, which conceivably reflects differences in translation of the transcripts. The conclusion made by Flamez et al. that FXYD2 $\gamma$ a production is essentially confined to islets is curious given its reported presence in the kidney [25], and the observation that this isoform is induced by stress and hyperosmolality in renal tubule cells and can completely replace the more widely produced FXYD1 as a regulator of $\mathrm{Na}+-\mathrm{K}+$ ATPase activity in these tissues [26, 27]. It should also be noted that FXYD2 $\gamma$ mutations cause renal hypomagnesaemia [28].

In terms of translating the current findings into a method for imaging islets in situ, it is more important that the signal from islets is orders of magnitude greater than the background of the rest of the pancreas [29], than whether or not it is expressed in other tissues, provided that they do not impede imaging. There appears to be a good prospect of this based on the immunohistochemical analyses of the two studies; however, in neither case was cell-surface binding convincingly demonstrated. This may be an issue for the presumed 6aa epitope within the 27aa extracellular domain of FXYD2 $\gamma a$, because of the potential for steric hindrance of antibody access due to other membrane components. The transmembrane domain of FXYD2 $\gamma$ probably interacts laterally with the $\mathrm{Na}^{+}-\mathrm{K}^{+}$ATPase $\beta$ subunit, a protein with a much larger, highly glycosylated extracellular domain. Nevertheless, one could envisage construction of a synthetic bivalent molecule that would combine the tissue specificity of SPY393 with a second low-affinity probe targeted at the adjacent ATPase $\beta$ subunit.

In addition to accessibility, antibody probes, be they humanised monoclonal antibodies or single chain constructs, present a challenge for monitoring disease progression or the effects of therapeutic intervention, as repeated administration is likely to lead to the generation of an immune response to the reagent. Thus neutralising antiidiotypic responses might be misinterpreted as evidence of loss of beta cell mass, and the potential for triggering a pathogenic anti-islet response also cannot be ignored. An alternative approach, analogous to dihydrotetrabenazine binding to the VMAT2 [30], would be to screen small molecule libraries for agents that specifically bind to the molecular targets of these antibodies rather than use them directly. In this context, the manuscripts by Flamez et al. and Ueberberg and colleagues are of wider importance in illustrating that there may be many more beta cell biomarkers to discover than those revealed from tissue transcriptomes alone-notably gene products that are alternatively spliced in a tissue-specific manner [16] and structurally diverse epitopes that can initially be defined by randomly generated molecular probes: in this instance, single chain antibodies [21].

Duality of interest The authors declare that there is no duality of interest associated with this manuscript.

\section{References}

1. Brogren CH, Hirsch F, Wood P, Druet P, Poussier P (1986) Production and characterization of a monoclonal islet cell surface autoantibody from the BB rat. Diabetologia 29:330-333

2. Powers AC, Rabizadeh A, Akeson R, Eisenbarth GS (1984) Characterization of monoclonal antibody $3 \mathrm{G} 5$ and utilization of this antibody to immobilize pancreatic islet cell gangliosides in a solid phase radioassay. Endocrinology 114:1338-1343

3. Alejandro R, Shienvold FL, Hajek SA, Pierce M, Paul R, Mintz DH (1984) A ganglioside antigen on the rat pancreatic B cell surface identified by monoclonal antibody R2D6. J Clin Invest $74: 25-38$

4. Bartholomeusz RK, Campbell IL, Harrison LC (1989) Pancreatic islet A2B5- and 3G5-reactive gangliosides are markers of differentiation in rat insulinoma cells. Endocrinology 124:2680-2685

5. Contreas G, Jorgensen J, Madsen OD (1990) Novel islet, duct, and acinar cell markers defined by monoclonal autoantibodies from prediabetic BB rats. Pancreas 5:540-547

6. Gadue P, Gouon-Evans V, Cheng X et al (2009) Generation of monoclonal antibodies specific for cell surface molecules expressed on early mouse endoderm. Stem Cells 27:2103-2113

7. Banerjee M, Otonkoski T (2009) A simple two-step protocol for the purification of human pancreatic beta cells. Diabetologia 52:621-625

8. Schneider S, Feilen PJ, Schreckenberger M et al (2005) In vitro and in vivo evaluation of novel glibenclamide derivatives as imaging agents for the non-invasive assessment of the pancreatic islet cell mass in animals and humans. Exp Clin Endocrinol Diab 113:388-395

9. Wild D, Behe M, Wicki A et al (2006) [Lys40(Ahx-DTPA-111In) $\mathrm{NH} 2$ ] exendin-4, a very promising ligand for glucagon-like peptide-1 (GLP-1) receptor targeting. J Nucl Med 47:2025-2033

10. Behnam Azad B, Rota VA, Breadner D, Dhanvantari S, Luyt LG (2010) Design, synthesis and in vitro characterization of glucagon-like peptide-1 derivatives for pancreatic beta cell imaging by SPECT. Bioorg Med Chem 18:1265-1272

11. Guerin B, Dumulon-Perreault V, Tremblay MC et al (2010) [Lys (DOTA)4JBVD15, a novel and potent neuropeptide $\mathrm{Y}$ analog designed for Y1 receptor-targeted breast tumor imaging. Bioorg Med Chem Lett 20:950-953

12. Harris PE, Ferrara C, Barba P, Polito T, Freeby M, Maffei A (2008) VMAT2 gene expression and function as it applies to imaging beta-cell mass. J Mol Med 86:5-16

13. Otonkoski T, Nanto-Salonen K, Seppanen M et al (2006) Noninvasive diagnosis of focal hyperinsulinism of infancy with [18F]-DOPA positron emission tomography. Diabetes 55:13-18 
14. Flamez D, Roland I, Berton A et al (2010) A genomic-based approach identifies FXYD domain containing ion transport regulator 2 (FXYD2) $\gamma$ a as a pancreatic beta cell-specific biomarker. Diabetologia. doi:10.1007/s00125-010-1714-z

15. Kutlu B, Burdick D, Baxter D et al (2009) Detailed transcriptome atlas of the pancreatic beta cell. BMC Med Genomics 2:3

16. Ortis F, Naamane N, Flamez D et al (2010) Cytokines interleukin1 beta and tumor necrosis factor-alpha regulate different transcriptional and alternative splicing networks in primary beta-cells. Diabetes 59:358-374

17. Neophytou PI, Muir EM, Hutton JC (1996) A subtractive cloning approach to the identification of mRNAs specifically expressed in pancreatic beta-cells. Diabetes 45:127-133

18. Juhl K, Sarkar SA, Wong R, Jensen J, Hutton JC (2008) Mouse pancreatic endocrine cell transcriptome defined in the embryonic Ngn3-null mouse. Diabetes 57:2755-2761

19. Ueberberg S, Schneider S (2010) Phage library-screening: a powerful approach for generation of targeting-agents specific for normal pancreatic islet-cells and islet-cell carcinoma in vivo. Regul Pept 160:1-8

20. Goletz S, Christensen PA, Kristensen P et al (2002) Selection of large diversities of antiidiotypic antibody fragments by phage display. J Mol Biol 315:1087-1097

21. Ueberberg S, Meier JJ, Waengler C et al (2009) Generation of novel single-chain antibodies by phage-display technology to direct imaging agents highly selective to pancreatic beta- or alphacells in vivo. Diabetes 58:2324-2334
22. Geering K (2006) FXYD proteins: new regulators of Na-KATPase. Am J Physiol Ren Physiol 290:F241-F250

23. Arystarkhova E, Donnet C, Asinovski NK, Sweadner KJ (2002) Differential regulation of renal Na, K-ATPase by splice variants of the gamma subunit. J Biol Chem 277:10162-10172

24. Arystarkhova E, Sweadner KJ (2005) Splice variants of the gamma subunit (FXYD2) and their significance in regulation of the Na, K-ATPase in kidney. J Bioenerg Biomembr 37:381-386

25. Arystarkhova E, Wetzel RK, Sweadner KJ (2002) Distribution and oligomeric association of splice forms of $\mathrm{Na}^{+}-\mathrm{K}^{+}$-ATPase regulatory gamma-subunit in rat kidney. Am J Physiol Ren Physiol 282:F393-F407

26. Wetzel RK, Pascoa JL, Arystarkhova E (2004) Stress-induced expression of the gamma subunit (FXYD2) modulates Na, KATPase activity and cell growth. J Biol Chem 279:41750-41757

27. Cairo ER, Swarts HG, Wilmer MJ et al (2009) FXYD2 and Na, KATPase expression in isolated human proximal tubular cells: disturbed upregulation on renal hypomagnesemia? J Membr Biol 231:117-124

28. Meij IC, Koenderink JB, van Bokhoven H et al (2000) Dominant isolated renal magnesium loss is caused by misrouting of the $\mathrm{Na}+$, K+-ATPase gamma-subunit. Nat Genet 26:265-266

29. Sweet IR, Cook DL, Lernmark A, Greenbaum CJ, Krohn KA (2004) Non-invasive imaging of beta cell mass: a quantitative analysis. Diab Technol Ther 6:652-659

30. Freeby M, Goland R, Ichise M, Maffei A, Leibel R, Harris P (2008) VMAT2 quantitation by PET as a biomarker for beta-cell mass in health and disease. Diab Obes Metab 10(Suppl 4):98-108 